\title{
PENGEMBANGAN MODUL FISIKA SMA BERBASIS SCIENCE TECHNOLOGY SOCIETY PADA MATERI ELASTISITAS UNTUK MENINGKATKAN MOTIVASI BELAJAR DAN HASIL BELAJAR SISWA
}

\author{
Yulia Dwisetyaningrum ${ }^{1}$, Sarwanto $^{2}$, Nonoh Siti Aminah ${ }^{3}$ \\ ${ }^{1}$ Program Studi Magister Pendidikan Sains FKIP Universitas Sebelas Maret \\ Surakarta, 57126, Indonesia \\ sherlock.yuki@gmail.com \\ ${ }^{2}$ Program Studi Magister Pendidikan Sains FKIP Universitas Sebelas Maret \\ Surakarta, 57126, Indonesia \\ sarwanto@fkip.uns.ac.id \\ ${ }^{3}$ Program Studi Magister Pendidikan Sains FKIP Universitas Sebelas Maret \\ Surakarta, 57126, Indonesia \\ nonoh_nst@yahoo.com
}

\begin{abstract}
Abstrak
Keberadaan modul fisika SMA yang mengaitkan konsep sains dan teknologi serta dampaknya ke masyarakat masih terbatas. Penelitian ini bertujuan untuk mengetahui karakteristik, mengukur kelayakan, dan mengukur peningkatan motivasi dan hasil belajar siswa pada penggunaan modul Fisika berbasis science technology society (STS) pada materi elastisitas. Penelitian ini merupakan penelitian dan pengembangan (R\&D) yang mengacu pada model Borg \& Gall yang dimodifikasi menjadi lima langkah. Modul yang sudah melalui tahap validasi ahli, guru, dan teman sejawat kemudian diujicobakan secara luas kepada 29 siswa. Hasil analisis data penelitian menunjukkan: 1) karakteristik modul adalah modul dikemas dalam tampilan yang menarik dan mudah digunakan, modul dikemas dengan menyajikan materi secara utuh, kegiatan belajar dalam modul bersifat saintifik yang mendukung Kurikulum 2013, dan modul menyajikan materi yang adaptif dan visioner; 2) kelayakan modul dilihat dari penilaian ahli, guru, teman sejawat yang memiliki nilai rata-rata di atas nilai cut off score $(89 \%>88 \%)$ dan penilaian produk oleh siswa $(84 \%>83 \%) 3$ ) Penggunaan modul Fisika SMA berbasis STS pada materi elastisitas dapat meningkatkan hasil belajar (n-gain kategori sedang) dan motivasi belajar siswa (n-gain kategori rendah) dan $79 \%$ siswa mencapai nilai Kriteria Ketuntasan Minimal (KKM).
\end{abstract}

Kata kunci: elastisitas, pengembangan modul, modul fisika, modul STS, motivasi belajar

\section{Pendahuluan}

Pelajaran Fisika SMA masih terkesan sulit untuk dipahami karena Fisika memiliki konsep yang abstrak dan tidak mudah dihubungkan dengan kejadian sehari-hari dalam kehidupan manusia (Rosenblum, 2008 : 1). Berdasarkan hasil analisis kebutuhan diketahui bahwa ketika pembelajaran fisika di kelas guru belum seara optimal mengaitkan konsep sains, teknologi, dan masyarakat. Buku teks yang digunakan pun belum mendukung proses sains dalam penyajiannya sehingga motivasi siswa dalam memplajari fisika sangat kurang. Berdasarkan hasil analisis kebutuhan siswa diketahui $60 \%$ siswa tidak antusias dalam mengikuti pembelajaran fisika. Kurangnya minat siswa untuk mengetahui masalah yang sedang dipelajari, mengindikasikan bahwa fisika belum menarik bagi siswa. Selain itu, siswa masih bertahan dengan paradigma bahwa Fisika merupakan mata pelajaran yang penuh dengan 
ungkapan matematis. Motivasi belajar ini berkaitan erat dengan keinginan siswa untuk belajar dan beraktifitas dalam pembelajaran sehingga siswa akan mengalami pembelajaran yang bermakna.

Pembelajaran yang bermakna salah satunya dapat dicapai dengan mengoptimalkan bahan ajar yang digunakan. Salah satu bahan ajar yang lengkap dan mandiri adalah modul. Modul Fisika yang baik dilengkapi dengan ilustrasi gambar yang menarik, ilustrasi konsep Fisika dengan kehidupan sehari-hari siswa, dan percobaan Fisika yang melibatkan aktifitas siswa. Modul akan lebih menarik dan menunjang pembelajaran bermakna apabila mengaitkan konsep sains yang dipelajari dengan perkembangan teknologi dan dampaknya terhadap masyarakat.

Modul yang dilengkapi dengan keterkaitan unsur sains, teknologi, dan masyarakat atau modul berbasis science, technology, society (STS) akan menarik minat siswa karena siswa mengetahui hubungan ilmu yang mereka pelajari dengan kehidupan mereka. Chantaranima (2014) menyatakan pembelajaran berbasis STS dapat membantu mereka mengembangkan konsep, pemanfaatan ilmu pengetahuan, kreativitas, sikap ilmiah, dan kemampuan menyelesaikan masalah. Keuntungan ini menuntun siswa untuk melihat objek abstrak dan konkrit pada kondisi konteks sosial sehingga mereka termotivasi untuk belajar dan dapat mengetahui tanggung jawab sosial mereka. Pembelajaran berbasis STS menanamkan kepada siswa bahwa dalam belajarnya tidak sekedar menghafal, tetapi siswa dapat bereksplorasi, bereksperimen, mengamati dan melihat langsung konsep-konsep materi pelajaran sehingga mendorong keingintahuan siswa pada sains dan teknologi lebih lanjut.
Berdasarkan uraian di atas, maka dilakukan penelitian tentang pengembangan modul fisika SMA berbasis STS dalam materi elastisitas untuk meningkatkan motivasi dan hasil belajar siswa. Penggunaan modul ini diharapkan dapat meningkatkan prestasi belajar siswa dan antusiasme siswa mempelajari ilmu fisika. Tujuan penelitian ini adalah : 1) mengetahui karakteristik modul Fisika SMA berbasis STS pada materi Elastisitas; 2) mengukur kelayakan modul Fisika SMA berbasis STS; dan 3) meningkatan hasil belajar dan motivasi belajar siswa setelah menggunakan modul Fisika SMA berbasis STS pada materi Elastisitas.

\section{Metode Penelitian}

Penelitian dilaksanakan di SMA IT Nur Hidayah Kartasura, Sukoharjo. Penelitian ini merupakan penelitian pengembangan menggunakan model R\&D Borg dan Gall dengan membatasi pada langkah ke-5 karena keterbatasan sumber daya yang ada. Adapun langkahlangkah pengembangan modul dijelaskan sebagai berikut:

1. Analisis Produk yang Akan Dikembangkan

Analisis ini meliputi analisis kebutuhan dan studi literatur. Analisis kebutuhan dilakukan dengan metode angket dan wawancara pada empat orang guru dan 40 siswa SMA kelas XI di Solo Raya. Studi literatur dilakukan untuk merencanakan dan menyusun bahan-bahan yang akan digunakan dalam modul.

2. Pengembangan Produk Awal

Tahap perencanaan terdiri atas 3 tahapan utama, yaitu 1) tahap penyusunan GBIM; 2) tahap penyusunan outline modul; dan 3) tahap pembuatan draf 1 modul. Tahap pembuatan draf 1 modul tersusun atas lima langkah, yaitu pengumpulan bahan, 
pembuatan rancangan bagian modul, pembuatan layout, mixing, dan finishing.

\section{Validasi Ahli dan Revisi}

Tahap validasi adalah tahapan yang bertujuan untuk menilai kualitas draf I modul meliputi komponen kelayakan isi, kelayakan bahasa, kelayakan penyajian, dan komponen kelayakan kegrafikan. Tahap validasi ini melibatkan dua dosen ahli dalam bidang pendidikan fisika, tiga guru Fisika SMA, dan dua teman sejawat.. Hasil revisi dari validasi ini dinamakan draf 2 modul.

4. Uji Coba Lapangan Skala Kecil dan Revisi

Tahap uji coba lapangan skala
kecil terhadap modul yang dikembangkan ini dilakukan dengan menggunakan draft 2 pada sepuluh siswa kelas X SMA IT Nur Hidayah dengan karakteristik siswa pandai, sedang, dan kurang pandai. Uji coba ini dilaksanakan untuk mengetahui gambaran umum kualitas modul serta kelebihan dan kelemahan modul sementara sebelum diuji cobakan secara lebih luas dalam pembelajaran di kelas. Hasil revisi modul dari uji coba ini dinamakan draf 3 modul.

5. Uji Coba Lapangan Skala Luas dan Produk Akhir

Uji coba lapangan skala luas menggunakan draf 3 modul yang dilaksanakan pada 29 siswa kelas XI IPA 1 SMA IT Nur Hidayah. Uji coba dilaksanakan dengan tujuan untuk mengetahui peningkatan motivasi dan hasil belajar siswa serta untuk mengevaluasi modul yang dikembangkan. Hasil revisi dari uji coba lapangan skala luas ini dinamakan produk akhir modul.

Teknik analisis data untuk kelayakan isi, kelayakan bahasa, kelayakan penyajian, dan kelayakan kegrafikan modul dilakukan dengan mengukur kelayakan modul dengan analisis cut off. Kelayakan modul diperoleh menggunakan teknik analisis cut off yang diadaptasi dari Winnie (2009).

Data peningkatan hasil belajar aspek pengetahuan menggunakan analisis n-gain yang diadaptasi dari Hake (1999) dengan mengukur peningkatan hasil pretest dan posttest. Data peningkatan hasil belajar aspek keterampilan dan sikap ilmiah menggunakan analisis lembar observasi untuk mengetahui peningkatan hasil belajar setiap pertemuan. Analisis peningkatan motivasi belajar siswa menggunakan n-gain yang diadaptasi dari Hake (1999) dengan mengukur peningkatan hasil pretest dan posttest serta analisis lembar observasi setiap pertemuan.

\section{Hasil Penelitian dan Pembahasan}

Hasil dari setiap tahapan prosedur pengembangan yang telah dilakukan adalah sebagai berikut:

\section{Hasil Analisis Produk yang Akan Dikembangkan}

Analisis diawali dengan identifikasi modul yang telah dikembangkan sebelumnya yaitu oleh Wulandari (2013) dan Yannurdanti (2013). Pengembangan modul yang telah disusun oleh keduanya sudah memenuhi sintaks-sintaks dalam pembelajaran STS. Akan tetapi, terdapat beberapa bahasa yang sulit dipahami serta tidak semua penyajian fenomena atau isu disertai dengan gambar pendukung, adanya gambar dapat membantu dalam proses pembentukan konsep. Pengembangan modul berbasis STS juga pernah dilakukan Faqih (2013) dan Nugraha (2011). Pengembangan modul yang disusun belum memenuhi sintaks pembelajaran STS. Di sisi lain, penyajian gambar yang disajikan oleh keduanya sangat baik dalam membantu proses pemahaman siswa.

Berdasarkan hasil analisis kebutuhan terhadap guru, dapat diketahui bahwa guru mengalami 
kendala dalam mengajarkan materi elastisitas kepada siswa sehingga siswa tidak antusias mengikuti pembelajaran fisika (terlihat dari 60\% siswa menyatakan tidak antusias mengikuti pembelajaran fisika), hal ini salah satunya disebabkan oleh keterbatasan buku teks yang dimiliki siswa. Mereka mengungkapkan bahwa buku teks yang dimiliki memiliki kekurangan yaitu format yang kurang menarik, terlalu verbalistis, penyajian materi terlalu instan, dan aplikasi fisika dalam kehidupan sehari-hari yang disuguhkan sedikit dan tidak terkini. Selain itu, terungkap bahwa tidak ada guru yang menggunakan modul dalam pembelajaran.

Hasil analisis kebutuhan siswa menunjukkan bahwa sebesar $60 \%$ responden kurang termotivasi dalam pembelajaran fisika dan $75 \%$ responden menyatakan bahwa pembelajaran fisika sulit karena membingungkan dan bersifat matematis (terlalu banyak rumus).

\section{Hasil Pengembangan Produk Awal}

Tahap pertama dalam mengembangkan produk awal ini yaitu penyusunan Garis Besar Isi Modul (GBIM). Langkah selanjutnya adalah pembuatan outline. Outline dibuat dengan tujuan mempermudah proses penulisan modul. Selain itu, dibuat juga skenario integrasi komponen motivasi ke dalam modul berbasis STS.

Konsultasi oleh ahli memberikan saran untuk memperbaiki desain modul. Revisi ini terdiri atas konsistensi penyusunan setiap bagian STS, penjelasan petunjuk penggunaan modul, serta perbaikan penyusunan peta konsep yang disesuaikan dengan panduan Novak dan Gowin (1982) kemudian perombakan jumlah kegiatan belajar (KB) dari tiga KB menjadi dua $\mathrm{KB}$ yang terdiri atas Tegangan, Regangan, dan Hukum Hooke untuk KB 1 kemudian Susunan Pegas dan Modulus
Elastisitas untuk KB 2. Revisi juga meliputi perombakan materi dasar mengenai elastisitas tentang susunan pegas dan modulus elastisitas. Modulus elastisitas didapatkan dari penemuan konsep melalui kegiatan percobaan susunan seri-paralel pegas.

Konsultasi ahli kedua memberikan saran agar merevisi pola keterkaitan antara STS dan motivasi belajar, desain isi kegiatan belajar, dan tata tulis. ilustrasi konsep supaya memperjelas konsep yang dijabarkan serta penambahan mengenai indikator di setiap soal evaluasi yang diberikan.

\section{Hasil Validasi Ahli dan Revisi}

Saran perbaikan terhadap modul yang dikembangkan juga diberikan oleh validator. Beberapa saran validator yaitu memperbaiki cover, memperbaiki kesalahan pengetikan, memberikan sumber gambar yang akurat, konsistensi penggunaan simbol, penonjolan komponen STS, dan penggunaan aktifitas belajar yang sesuai dengan proses penemuan.

Revisi dari hasil validasi ini meliputi pertama, bagian cover yang mulanya lebih menonjolkan model daripada busur panah diubah menjadi ilustrasi memanah yang berfokus pada busur panah yang meregang sehingga mencerminkan isi dari modul yaitu elastisitas. Kedua, beberapa kesalahan penulisan kata dan istilah diperbaiki serta melengkapi sumber gambar ilustrasi dalam modul. Ketiga, simbol modulus elastisitas yang semula tidak konsisten antara E (modulus elastisitas) dan Y (modulus Young) kemudian diubah menjadi $\mathrm{E}$ agar konsisten dan tidak membingungkan pembaca. Keempat, kalimat pertanyaan dan kolom jawaban pada modul diperbaiki sehingga siswa lebih mudah menemukan konsep.

Hasil penilaian tahap validasi dijabarkan pada Tabel 1. 
Tabel 1. Analisis Cut Off Tahap Validasi

\begin{tabular}{|c|c|}
\hline Validator & Keidealan $(\%)$ \\
\hline 1. Ahli Materi & 90 \\
\hline 2. Ahli Media & 82 \\
\hline 3. Ahli Bahasa & 84 \\
\hline 4. Guru I & 86 \\
\hline 5. Guru II & 93 \\
\hline 6. Teman Sejawat I & 94 \\
\hline 7. Teman Sejawat II & 95 \\
\hline Nilai Maksimum & 95 \\
\hline Nilai Minimum & 82 \\
\hline Natural Cut off Score & 88 \\
\hline Nilai Rata-rata & 89 \\
\hline Keterangan & Lavak \\
\hline
\end{tabular}

Tabel 1 menunjukkan bahwa nilai rata-rata hasil penilaian lebih besar daripada nilai cut off, maka dapat disimpulakan bahwa modul tersebut layak.

\section{Hasil Uji Coba Lapangan Skala Kecil dan Revisi}

Uji coba I (uji coba terbatas) dilakukan selama 1 minggu kepada 10 siswa. Siswa diberi waktu selama seminggu untuk mempelajari modul dengan dua kali pertemuan untuk memantau perkembangan pembelajaran siswa. Pada pertemuan terakhir, siswa diberi angket respon terhadap modul. Hasil uji coba lapangan skala kecil adalah analisis jawaban siswa atas pertanyaan di dalam modul dan saran yang diberikan siswa. Perbaikan dilakukan jika ada kesalahan di dalam modul dan jawaban siswa tidak sesuai dengan kunci jawaban serta revisi penambahan kolom tabel, grafik, dan aktifitas pembelajaran di dalam modul. Modul hasil revisi uji coba lapangan skala kecil ini disebut draf 3 .

\section{Hasil Uji Coba Skala Luas dan Produk Akhir}

Uji coba lapangan skala luas dilakukan pada 29 siswa dalam tiga kali pertemuan. Data yang diperoleh dalam uji coba lapangan skala luas meliputi data hasil belajar siswa aspek pengetahuan dan motivasi belajar (Tabel
2 dan Tabel 3), hasil belajar aspek keterampilan (Gambar 1), hasil belajar aspek sikap ilmiah (Tabel 4), dan penilaian siswa terhadap modul. Berikut hasil rincian data uji coba skala lapangan skala luas.

Tabel 2. Peningkatan Motivasi Belajar Pada Setiap Indikator

Indikator Motivasi Belajar $\quad \mathrm{N}-$

$\begin{array}{ll}\text { Gai } & \text { n }\end{array}$

Tekun dalam menghadapi tugas $\quad 0.15$

Ulet dalam menghadapi kesulitan $\quad 0.18$

Menunjukkan minat $\quad 0.19$

Senang bekerja mandiri $\quad 0.21$

Cepat bosan pada tugas rutin $\quad 0.25$

Dapat mempertahankan pendapatnya $\quad 0.28$

Tidak mudah melepas hal yang diyakini $\quad 0.23$

Senang mencari dan memecahkan 0.19 masalah soal-soal

Berdasarkan hasil perhitungan

$\mathrm{N}$-gain ternormalisasi diperoleh rata-rata motivasi belajar dilihat dari setiap indikator adalah berbeda. Peningkatan paling tiggi terjadi pada infikator dapat mepertahankan pendapat kemudian peningkatan paking rendah terjadi pada indikator tekun dalam menghadapi tugas.

Tabel 3. Peningkatan Hasil Belajar dan Motivasi Bealjar

\begin{tabular}{cccc}
\hline Kemampuan & Tes & Mean & $\begin{array}{c}\text { N- } \\
\text { Gain }\end{array}$ \\
\hline $\begin{array}{c}\text { HB Aspek } \\
\text { Pengetahuan }\end{array}$ & $\begin{array}{c}\text { Pretest } \\
\text { Posttest }\end{array}$ & 5,34 & \\
Motivasi & Pretest & 2,76 & 0,53 \\
Belajar & Posttest & 2,92 & 0,21 \\
\hline
\end{tabular}

Hasil perhitungan n-gain menurut Hake (1999) untuk peningkatan hasil belajar aspek pengetahuan adalah "sedang" sedangkan untuk motivasi belajar adalah "rendah".

Hasil belajar aspek keterampilan juga diukur dalam uji coba lapangan skala luas. 


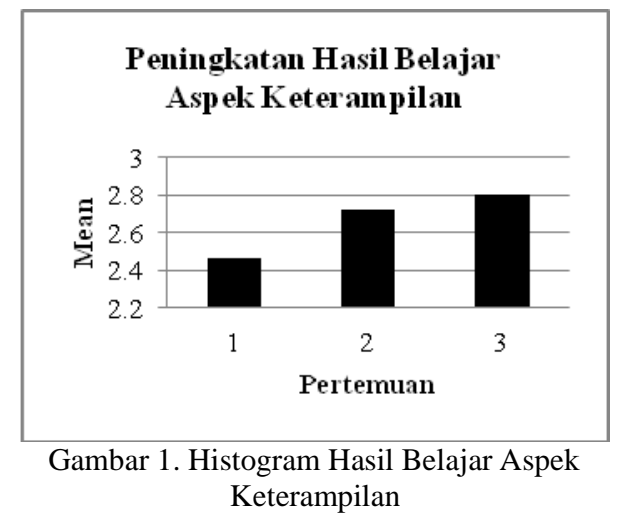

Gambar 1 menunjukkan peningkatan hasil belajar aspek keterampilan pada setiap pertemuan. Hasil belajar aspek sikap ilmiah dijabarkan dalam Tabel 2 berikut ini.

\begin{tabular}{cccc}
\multicolumn{4}{c}{ Tabel 4. Hasil Belajar Sikap Ilmiah } \\
\hline Pertemuan & Aspek & $\mathrm{X}$ & $\mathrm{Y}$ \\
\hline 1 & $\begin{array}{c}\text { Rasa ingin } \\
\text { tahu }\end{array}$ & 2,96 & 2,94 \\
& Teliti & 2,93 & \\
& Disiplin & 3,03 & 3,23 \\
2 & Kerja keras & 3,44 & \\
\multirow{2}{*}{3} & Kreatif & 3,37 & 3,30 \\
& Jujur & 3,24 & \\
\hline Rerata & & & 3,15 \\
\hline
\end{tabular}

X: Rata-rata ; Y: rata-rata tiap pertemuan

Tabel 4 menunjukkan rata-rata aspek sikap ilmiah siswa dalam setiap pertemuan meningkat dengan rata-rata keseluruhan yaitu 3,15 dengan kategori "baik". Kelayakan modul pada uji coba lapangan skala luas diukur menggunakan analisis cut off untuk penilaian produk oleh siswa.

Nilai rata-rata penilaian produk oleh siswa yaitu $84 \%$ lebih dari nilai natural cut off score sejumlah 83\% maka produk dinyatakan layak. Tahap selanjutnya adalah merevisi draf 3 modul berdasarkan hasil pada uji coba diperluas. Beberapa revisi dari hasil uji coba lapangan skala luas adalah mengenai revisi kunci jawaban yang dilengkapi dengan teks serta penambahan konsep elastisitas zat cair dan gas agar siswa memahami konsep elastisitas sebaga karakteristik suatu bahan. Hasil revisi dari draf 3 ini merupakan produk akhir modul.

\section{Pembahasan}

\section{1) Karakteristik Modul}

Modul yang dikembangkan menggunakan basis STS dan diterapkan pada materi elastisitas. Modul terdiri atas dua kegiatan belajar yaitu "tegngan, regangan, dan hukum Hooke" kemudian "susunan pegas dan modulus elastisitas". Sintaksis pembelajaran STS yaitu inisiasi, pembentukan konsep, aplikasi konsep, pemantapan konsep, dan evaluasi diterapkan dalam modul.

Karakteristik modul STS yang pertama adalah modul dikemas dalam tampilan yang menarik dan mudah digunakan. Salah satu ciri modul yang baik menurut Depdiknas (2008) Langkah dalam setiap kegiatan ekperimen disusun menggunakan kalimat yang sederhana dan jelas sehingga meminimalisasi kesalahan dalam pelaksanaan. Kolom jawaban disediakan sesuai dengan jawaban yang diharapkan. Instruksi dari setiap kegiatan juga telah menggunakan kalimat yang jelas dan mudah dipahami.

Karakteristik modul yang kedua adalah modul dikemas dengan menyajikan materi secara utuh sesuai dengan karakteristik modul yang baik oleh Depdiknas (2008). Kompetensi inti, standar kompetensi, kompetensi dasar, dan tujuan dari setiap kegiatan belajar dijabarkan secara jelas sebelum siswa melakukan pembelajaran sehingga guru dan siswa mengetahui kompetensi apa saja yang akan mereka capai setelah melakukan pembelajaran. Pembelajaran dalam modul mengacu pada karakteristik pembelajaran STS oleh Fajar (2009) yaitu keikutsertaan yang aktif dari siswa dalam mencari informasi yang dapat diterapkan untuk memecahkan masalah dalam kehidupan sehari-hari. Selain itu, sikap ilmiah siswa dikembangkan melalui kegiatankegiatan yang merangsang rasa ingin tahu, sikap saling menghargai, jujur, tekun, dan sebagainya. Pernyataan ini 
sesuai dengan penelitian yang pernah dilakukan oleh Chantaranima (2014) yang menyatakan pembelajaran berbasis STS dapat membantu mereka sikap ilmiah dan kemampuan menyelesaikan masalah.

Karakteristik modul yang ketiga adalah kegiatan belajar dalam modul bersifat saintifik yang mendukung Kurikulum 2013. Karakteristik ketiga ini sesuai dengan pendapat Kumar dan Chubin (2000) memaparkan bahwa literasi sains merupakan fondasi dalam pembelajaran STS.

Karakteristik modul yang keempat adalah modul menyajikan materi yang adaptif dan visioner. Karakteristik ini diadaptasi oleh karakteristik modul yang baik oleh Depdiknas (2008). Adaptif yaitu materi yang disajikan menyesuaikan dengan perkembangan sains dan teknologi terkini. Visioner kemudian adalah modul menyajikan uraian agar siswa berpikir mengenai dampak perkembangan sains dan teknologi di masa depan.

Modul yang disusun berbasis STS ini masih memiliki beberapa kekurangan. Pembahasan mengenai konsep elastisitas zat padat hendaknya dikaitkan dengan elastisitas zat cair dan gas (fluida) sehingga siswa mampu mengidentifikasi esensi dari konsep elastisitas yaitu sebagai karakteristik suatu bahan tidak hanya tentang pegas. Kaitan ini dapat diterapkan melalui aplikasi teknologi terkini mengenai elastisitas fluida.

Aspek sains dan teknologi juga belum terlihat pada aspek masyarakat. Poedjiadi (2010) memaparkan pembelajaran STS seharusnya mengaitkan sains dengan teknologi serta kegunaan dan kebutuhan masyarakat. Konsep yang telah dipelajari dan dikuasai siswa diharapkan dapat bermanfaat bagi dirinya dan dapat digunakan untuk menyelesaikan masalah yang dihadapinya maupun masalah lingkungan sosialnya.
Sikap siswa sebagai konsekuensi anggota masyarakat kaitannya dengan tindakan penyelesaian masalah menuntut pmbelajaran baik formal maupun nonformal diharapkan dapat memberikan pengalaman kepada siswa melalui "learning to know, learning to do, learning to be dan learning to live together" sesuai anjuran oleh UNESCO yang ditulis oleh Delors (1996). Model pembelajaran berbasis STS sangat sesuai dengan empat pilar pendidikan yang direkomendasikan oleh UNESCO. Kesesuaian tersebut antara lain belajar untuk mengetahui (learning to know) mereka dapat berfikir kreatif untuk mengetahui akar permasalahan yang akan dikaji. Belajar untuk melakukan (learning to do) merupakan keterampilan memecahkan masalah dalam bertindak, belajar untuk menjadi manusia mandiri yang utuh (learning to be) dan belajar untuk bekerjasama dalam kelompok masyarakat (learning to live together).

Kekurangan modul ini semoga memberikan gambaran terhadap pengembangan modul berbasis STS selanjutnya agar mampu mengaitkan konsep pembelajaran dengan empat pilar pendidikan dan konteks teknologi serta masyarakat.

\section{Kelayakan Modul}

Kelayakan modul Elastisitas dan hokum Hooke berbasis STS telah diuji melalui tahap validasi ahli, penilaian praktisi, penilaian teman sejawat (peer reviewer), dan penilaian modul oleh siswa. Hasil validasi ahli menunjukkan bahwa modul sudah layak sesuai dengan tujuan pengembangan karena memiliki kategori sangat baik menurut ahli materi dan media, guru, teman sejawat, dan siswa berdasarkan hasil analisis cut off score. Nilai rata-rata penilaian modul di atas nilai natural cut off score sehingga modul dikatakan layak. Modul dinilai layak karena telah memenuhi kriteria modul. 
Berdasarkan respon yang diterima, siswa menanggapi penggunaan modul dengan positif. Melalui modul ini, siswa menjadi lebih tertarik untuk belajar materi Elastisitas dan hokum Hooke karena modul ini menyajikan penerapan konsep fisika dalam dunia teknologi dan fenomena yang sering terjadi di masyarakat. Materi yang berkaitan langsung dengan kehidupan membuat siswa lebih mudah dalam memahaminya. Hal ini sesuai dengan hasil penelitian Surmeli (2012) menyimpulkan bahwa sikap positif mahasiswa terhadap perkuliahan menggunakan STS yaitu ketertarikan, visualisasi, sikap positif, dan membantu mereka menghubungkan konsep ilmu pengetahuan dengan kehidupan seharihari.

Menurut siswa modul yang dikembangkan mudah dipahami, penyajian materi dalam modul sudah cukup lengkap, permasalahan yang dikemukakan berkaitan erat di lingkungan sekitar siswa, dan modul yang disajikan secara berwarna dan dilengkapi gambar-gambar yang menarik. Hal tersebut senada dengan pandangan Yager (2009) dengan penekanan memperhatikan siswa, lingkungannya dan kerangka pikir. Strategi pembelajarannya dimulai dari penerapan pada dunia nyata, menuju dunia teknologi dan kemudian dunia siswa. Siswa merasa senang dengan adanya modul yang dikaitkan dengan fenomena di sekitar karena merasa mendapat pengalaman baru dalam menerapkan pengetahuan yang dimiliki untuk melakukan analisis dan pemecahan masalah terhadap kejadian sehari-hari di lingkungannya.

\section{Peningkatan Motivasi Belajar dan Hasil Belajar Siswa Setelah Menggunakan Modul}

Hasil belajar siswa yang diamati dalam penelitian ini meliputi aspek pengetahuan, aspek keterampilan, aspek sikap.

\section{a. Hasil Belajar Aspek Pengetahuan (kognitif)}

Hasil belajar aspek pengetahuan diperoleh dari nilai pretest dan posttest. Kenaikan hasil belajar aspek pengetahuan yang telah dianalisis menggunakan $\mathrm{N}$-gain menurut Hake (1999) kenaikan rata-rata hasil belajar yaitu 0,53 dengan kategori "sedang". Hasil belajar aspek pengetahuan yang mempunyai rata-rata 7,81 telah memenuhi KKM (KKM SMA IT Nur Hidayah sebesar 7,5).

Sumintono (2008:3) menyatakan titik penekanan dari pola pembelajaran STS adalah mengembangkan hubungan antara pengetahuan ilmiah siswa dengan pengalaman keseharian mereka. Asy'ari (2006: 81) menyatakan basis STS memiliki nilai tambah diantaranya 1) basis STS dapat membuat pembelajaran lebih bermakna; 2) memperluas wawasan siswa tentang keterkaitan sains dengan bidang studi lain; 3) membuat siswa dapat menikmati kegiatankegiatan sains dengan perolehan pengetahuan yang tidak mudah dilupakan; 4) dapat bertanggung jawab atas masalah yang muncul di lingkungan dan; 5) dapat mengembangkan pembelajaran terpadu.

$$
\text { Wenno (2010: }
$$

mengemukakan bahwa melakukan pembelajaran dengan modul membuat siswa lebih mudah memahami konsep/materi sehingga hasil belajar siswa dapat meningkat. Pembelajaran yang baik dan menyenangkan adalah pembelajaran yang memberikan kesempatan kepada siswa tentang ide/gagasan yang dimiliki. Proses pembelajaran tersebut akan mendorong siswa untuk terlibat secara aktif, dan membangun pengetahuan, sikap, serta perilaku.

Beberapa kendala dalam pembelajaran pengetahuan oleh siswa adalah sebagai berikut: 1) pada 
pertemuan pertama, siswa kurang dapat mengikuti pola discovery atau penemuan dalam tahap inisiasi sehingga peran guru masih cukup dominan; 2) kemampuan berfikir analisis siswa belum dapat menjangkau pertanyaan-pertanyaan dalam modul terutama dalam pertanyaan eksperimen tetapi pada KB 2 kemampuan ini sudah cukup berkembang, sehingga siswa dapat mengerjakan soal dan menjawab pertanyaan dalam modul secara mandiri; 3) Analisis penemuan persamaan modulus elastisitas melalui percobaan rangkaian pegas seri-paralel masih cukup menyulitkan siswa. Petunjuk penemuan persamaan perlu ditambahkan dalam modul.

\section{b. Hasil Belajar Aspek Keterampilan (Psikomotorik)}

Berdasarkan hasil analisis, hasil belajar aspek keterampilan mengalami kenaikan pada setiap pertemuan. Hasil analisis dapat dilihat pada Tabel 3 yang menunjukkan bahwa rerata hasil belajar aspek keterampilan pada pertemuan I adalah 2,46 dengan kriteria "Cukup", rerata pertemuan II sebesar 2,72 dengan kriteria "Baik", dan rerata pertemuan III sebesar 2,80 dengan kriteria "Baik. Rerata skor hasil belajar aspek keterampilan dari empat pertemuan yaitu 2,66 dengan kriteria "Cukup".

Kenaikan tersebut dikarenakan siswa telah terbiasa menggunakan metode eksperimen dalam pembelajaran, sehingga keterampilan siswa dalam penggunaan alat juga semakin baik. Depdiknas (2008: 7) mengemukakan bahwa pelajaran sains memfokuskan kegiatan pada penemuan dan pengolahan informasi melalui kegiatan mengamati, mengukur, mengajukan pertanyaan, mengklasifikasi, memecahkan masalah, dan sebagainya. Hal senada juga dikemukakan oleh Rahayu dkk (2013: 133), bahwa nilai rata-rata aspek psikomotorik mengalami peningkatan karena siswa terlibat aktif dan lebih terarah saat eksperimen.
Pendekatan STS menjadikan siswa lebih aktif selama proses pembelajaran, karena dalam pendekatan STS terdapat tahap pembentukan konsep. Pada tahap pembentukan konsep siswa melakukan eksperimen.

Namun, di dalam uji lapangan ditemukan beberapa kendala, terutama pada pertemuan pertama antara lain: 1) ketika eksperimen dan berdiskusi secara berkelompok hanya beberapa siswa yang dominan aktif, 2) kondisi pada saat pertemuan pertama kurang baik, hal ini dikarenakan siswa belum terbiasa melakukan pembelajaran dengan modul yang disertai eksperimen, 3) beberapa siswa tidak serius ketika melakukan eksperimen, 4) tidak semua kelompok dapat melakukan presentasi di depan kelas, 5) kemampuan siswa dalam membuat table dan grafik masih kurang. 6) beberapa siswa tidak mengerjakan tugas pada modul. Akan tetapi, pada pertemuan kedua dan seterusnya kondisi pembelajaran sudah lebih baik dan waktu pembelajaran lebih efektif. Tugas di dalam modul juga sudah dikerjakan oleh siswa, serta kerja sama siswa dalam kelompok semakin baik. Hal ini dikarenakan siswa sudah mulai terbiasa belajar menggunakan modul yang disertai dengan eksperimen.

\section{c. Hasil Belajar Aspek Sikap Ilmiah}

Hasil analisis skor rerata hasil belajar aspek sikap ilmiah dapat dilihat pada Tabel 4 yang menunjukkan bahwa rerata hasil belajar aspek sikap meningkat setiap pertemuannya.

Poedjiadi (2010) menjelaskan bahwa salah satu ranah yang terlibat dalam model pembelajaran STS adalah sikap. Sikap mencakup menyadari kebesaran Tuhan, menghargai hasil penemuan ilmuan dan penemu produk teknologi tetapi menyadari kemungkinan adanya dampak negatif produk teknologi, serta memelihara kelestarian lingkungan. Peningkatan ini dikarenakan pembelajaran dengan basis STS memberikan ruang dan kesempatan 
siswa untuk berinteraksi sosial dengan teman sekelompoknya. Tahap invitasi pada awal pembelajaran dapat menumbuhkan rasa ingin tahu siswa untuk belajar lebih dalam lagi. Tahap pembentukan konsep melalui metode eksperimen siswa dapat belajar untuk bekerja sama, menghargai pendapat temannya, kreatif, tanggung jawab, dan cermat. Selain itu, pada tahap aplikasi konsep dan pemantapan konsep siswa dituntut untuk belajar dengan tekun dan cermat. Selanjutnya, pada tahap evaluasi siswa dapat berlatih untuk bersikap jujur selama mengerjakan tes formatif yang ada pada modul.

\section{d. Peningkatan Motivasi Belajar Siswa setelah Menggunakan Modul}

Peningkatan motivasi belajar diukur pada setiap indikator motivasi belajar yang diadaptasi dari Sardiman (2001) yaitu tekun dalam menghadapi tugas, ulet dalam menghadapi kesulitan, menunjukkan minat, senang bekerja mandiri, cepat bosan pada tugas rutin, dapat mempertahankan pendapatnya, tidak mudah melepas hal yang diyakini, serta senang mencari dan memecahkan masalah soal-soal. Peningkatan paling tinggi yaitu sebesar 0,28 terjadi pada indikator dapat mempertahanan pendapat. Hal ini berkaitan dengan kemampuan awal dan minat awal siswa yaitu senang berdiskusi dan mengemukakan pendapat di depan umum. Penggunaan modul yang mendukung siswa untuk aktif berdiskusi dan bertukar pendapat juga mengakibatkan peningkatan motivasi belajar semakin besar. Peningkatan paling rendah kemudian terjadi pada indikator tekun dalam menghadapi tugas. Tugas ini terutama pada tugas mengerjakan soal evaluasi dan pekerjaan rumah. Siswa berpendapat bahwa waktu untuk mengerjakan soal dan derajad kesulitan soal tidak sesuai karena waktu penelitian terbatas. Selain itu, pekerjaan rumah tidak dikerjakan secara optimal dikarenakan beban tugas dari beberapa mata pelajaran sudah banyak. Permasalahan ini menjadi masukan untuk pengembangan modul selanjutnya supaya penyusunan evaluasi di dalam modul menyesuaikan alokasi waktu yang ada.

Temuan di lapangan menunjukkan bahwa siswa awalnya tidak begitu aktif dalam kegiatan pembelajaran saat disajikan ilustrasi awal. Namun, siswa mulai aktif dan bekerja sama dengan temannya saat memasuki aktifitas siswa seperti percobaan dan demonstrasi. Temuan ini senada dengan Rahmadiyati (2007) yang menyatakan bahwa salah satu faktor yang mempengaruhi motivasi belajar adalah pengalaman dengan lingkungan yang membuat seseorang bersifat aktif. Hal ini dapat menjadi masukan bagi pengembangan modul berikutnya agar mengawali kegiatan pembelajaran dengan aktifitas siswa sehingga motivasi belajar dan hasil belajar siswa dapat dicapai secara maksimal.

\section{Kesimpulan dan Rekomendasi}

Berdasarkan hasil analisis data disimpulkan: 1) Karakteristik modul adalah modul dikemas dalam tampilan yang menarik dan mudah digunakan, modul dikemas dengan menyajikan materi secara utuh, kegiatan belajar dalam modul bersifat saintifik yang mendukung Kurikulum 2013, dan modul menyajikan materi yang adaptif dan visioner; 2) modul Fisika SMA berbasis STS pada materi elastisitas telah divalidasi oleh ahli, praktisi, dan peerreviewer dinyatakan layak.; 3) penggunaan modul Fisika SMA berbasis STS pada materi elastisitas dapat meningkatkan hasil belajar dan motivasi belajar siswa.

\section{Daftar Pustaka}

Amin. (2009). Studi Kelayakan Fasilitas Fisik dan Kemampuan Guru Dalam 
INKUIRI: Jurnal Pendidikan IPA

Vol. 8, No. 1, 2019 (hal 29-39)

https://jurnal.uns.ac.id/inkuiri

Menunjang Pelaksanaan

Pembelajran Berbasis Teknologi

Informasi di Jurusan Teknik

Elektro SMK 2 Pengasih.

Yogyakarta: Universitas Negeri

Yogyakarta.

Asy'ari, M. (2006). Penerapan Pendekatan Sains-TeknologiMasyarakat dalam Pembelajaran Sains di Sekolah Dasar. Jakarta: Depdiknas

Chantaranima, T \& Yuenyong, C. (2014). The Outcomes of Teaching and Learning About Sound Based on Science Technology and Society (STS). Procedia-Social and Behavioral Sciences, 116 : $2286-$ 2292.

Delors, J., et al. (1996). Learning: The Treasure Within. Paris : UNESCO.

Depdiknas. (2006). Standar Kompetensi Pembelajaran Fisika. Jakarta: Balitbang.

Depdiknas. (2008). Teknik Penyusunan Modul. Jakarta: Depdiknas

Fajar, A. (2009). Portofolio dalam Pembelajaran IPS. Bandung: PT Remaja Rosdakarya

Hake, R.R. (1999). Analyzing Gain/Change Scores. Diperoleh 2 Juli 2016 dari http://lists.asu.edu/

Kumar, D. D. \& Daryl E. C. (2000). STS: Adding Value to Research and Practice. Journal of Science Education and Technology, 9 (2) : 136

Poedjiadi, A. (2010). Sains Teknologi Masyarakat. Bandung: PT Remaja Rosdakarya.

Rahayu, S., Widodo, A.T., \& Sudarmin. (2013). Pengembangan Perangkat Pembelajaran Model POE Berbantu Media "I am Scientist". Inovative Journal of Curriculum and Educational Technology. 2(1) : 128-133.

Rahmadiyati, A.S. (2007). Meningkatkan Motivasi Belajar Siswa Kelas II Melalui Penerapan Alat Peraga Gambar pada Mata Belajaran
Bahasa Indonesia. Diperoleh 5 Desember 2016 dari http://digilib.unnes.ac.id/

Rosenblum, B. (2008). How to Study Physics. Diperoleh 4 Desember 2015 dari http://griffin.ucsc.edu/

Sardiman. (2001). Interaksi dan Motivas Belajar Mengajar. Jakarta : Rajawali Pers.

Sumintono, B. (2008). Mengemas Sains, Teknologi dan Masyarakat dalam Pengajaran Sekolah. (diakses melalui netsains.net pada tanggal 13 Agustus 2014)

Surmeli, H. (2012). Examination The Effect Of Science Fiction Films On Science Education Students' Attitudes Towards STS Course. Procedia - Social and Behavioral Sciences, 47 :1012 - 1016

Wenno, I. H. (2010). Pengembangan Modul Model IPA berbasis Problem Solving Method berdasarkan Karakteristik Siswa dalam Pembelajaran di SMP/MTs. XXIX(2):176-188

Winnie, S. (2009). Pendekatan Kombinasi AHP dan Metode Cut Off Point pada Tahap Analisis Keputusan Perancangan Sistem Informasi Penjualan. J@Ti Undip, IV (3) : 218-233

Yager, R. E, et al. (2009). A Comparison of Student Learning in STS vs Those in Directed Inquiry Classes. Electronic Journal of Science Education, 13 (2) : 186-208 